\title{
Level of Serum Electrolytes in Chronic Alcoholic \\ Patients
}

\author{
Mithileshwer Raut $^{{ }^{*}}$, Sangita Ghimire ${ }^{2}$, Prashant Regmi ${ }^{3}$, Sanjay Kumar Raut ${ }^{4}$, Bharat Jha ${ }^{1}$
}

BACKGROUND: The aim of this study is to establish serum levels of sodium, potassium, magnesium, calcium and phosphorus in chronic alcoholic patients.

METHODS: This cross-sectional study was conducted in Tribhuvan University Teaching Hospital (TUTH). A total of 90 chronic alcoholic patients visiting to psychiatry department of TUTH were included in the study. Age of patients ranges from 20-50 years. Study also included 90 non-alcoholic healthy controls that were age matched.

RESULTS: Among the 90 chronic alcoholic patients and 90 normal healthy controls, majority of patients $(95.5 \%)$ and controls (82\%) were male, only few patients were female $(4.5 \%)$. The mean age of the cases and controls were $35.42 \pm 5.6$ years, $34.53 \pm 3.5$ years respectively. In this study, the mean values of Serum Sodium and Potassium were lower in cases $(133.58 \pm 7.8$, sodium and $3.64 \pm 0.65$, potassium $)$ as compared to controls ( $139.43 \pm 3.85$, sodium and $4.15 \pm 0.43$, potassium) with the significant correlation in both groups $(\mathrm{p}<0.001)$. Calcium, phosphorus and magnesium level was depleted in cases compared to control groups.

CONCLUSIONS: Hyponatremia and hypokalemia are the most common electrolyte abnormalities observed in chronic alcoholic patients.

(C) 2015 Nepalese Association for Clinical Chemistry

\section{Introduction}

Alcohol consumption can be the cause of several diseases, and it is, well known, the high burden of its consumption over mortality around the world [1].Alcohol permeates all tissues of the body and affects most vital functions, because it is a small molecule soluble in both water and lipids [2]. Alcohol crosses capillary membranes by simple diffusion, affecting almost every organ system in the body by impacting a wide range of cellular functions. The liver is the organ most severely affected by alcoholism. Alcohol abuse is a major health problem as well as social problem in the community. Alcohol causes metabolic derangements either directly, via its chemical by- product or secondarily through alcohol-induced disorders. Many of these alcohol-related metabolic disturbances are increased in severity by the malnutrition that is common in those with chronic alcoholism. The aim of this study is to establish serum levels of sodium, potassium, magnesium and calcium in chronic alcoholic patients.

\section{Methods}

This cross-sectional study was conducted in Tribhuvan University Teaching Hospital. Chronic alcoholic patients (consuming alcohol for more than five years, 15 drinks per week) between age group 20-50 years visiting the psychiatry department of TUTH were included in the study. Patients with associated liver disease and pancreatic diseases and alcoholics undergoing treatment were not included in our study. Ninety chronic alcoholic patients and 90 healthy controls both male and female were enrolled as participants. Blood Pressure and other anthropometric parameters were measured while blood samples were analyzed for serum electrolytes level. Ion selective electrode [3] was used for the determination of sodium and potassium. Serum calcium was measured by CPC (o-cresolphthalein-complexone) [4] method, serum phosphate by precipitate method [5] and serum magnesium by Calmagite method [6]. Laboratory standard operation procedures were followed for laboratory testing and analysis of serum samples. Internal quality control sera, both normal and pathological, were also run for each lot of the test, for the validation of the results. SPSS program was used to analyze data, t-test $\&$ Spearman's correlation coefficient was used to find correlation.

\section{Results}

Age of participants was between $25-47$ years with mean age of $35.42 \pm 5.6$ years and $34.53 \pm 3.5$

\footnotetext{
'Department of Biochemistry, Maharjgunj Medical Campus, IOM, TUTH, Nepal. ${ }^{2}$ Department of Microbiology, TUTH, Nepal. ${ }^{3}$ Department of Biochemistry, Nepal Medical College, Jorpati, Nepal. ${ }^{4}$ Department of Chemistry, Tri-Chandra College, Kathmandu, Nepal.
} 
years for patients and controls respectively. The average daily intake of alcohol as stated by the patients was 71.36 gms. The mean duration of drinking was 12.0 years (range 5-28 years). The frequency of consumption was daily in $48 \%$ patients, 3-5 times a week in $41 \%$ patients. The majority of chronic alcoholic patients (72\%) consumed alcohol alone while $28 \%$ claimed to drink only in company.
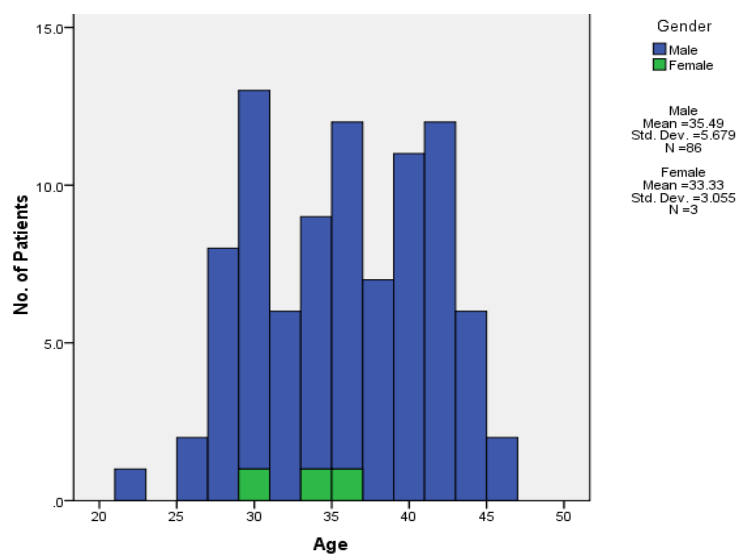

Figure 1. Age and gender-wise distribution of cases

Of the total 90 chronic alcoholics, majority of the patients both males and females were between 3335 years of age group. Men were more in numbers as chronic drinkers in comparison to women.

The mean values of serum sodium and potassium were lower in cases as compared to controls $(133.58 \pm 7.8$ sodium and $3.64 \pm 0.65$ potassium, in cases; compared to $139.43 \pm 3.85$, sodium and $4.15 \pm 0.43$, potassium, in controls), with the mean values, however, within the normal range for potassium in both groups $(\mathrm{p}<0.001)$ [Table 1].

Also, 44 patients $(50 \%)$ had a borderline hyponatremia $(<135 \mathrm{mmol} / \mathrm{L})$, and 28 patients $(31 \%)$ had borderline hypokalemia $\quad<3.5$ $\mathrm{mmol} / \mathrm{L}$ ) [Figure 1]. Mean calcium, phosphorus and magnesium levels were also decreased in cases as compared to controls.

Table 1. Comparison of mean of electrolytes between cases and controls

\begin{tabular}{lccc}
\hline Parameters & $\begin{array}{c}\text { Control } \\
\text { Mean } \pm \text { SD }\end{array}$ & $\begin{array}{c}\text { Case } \\
\text { Mean } \pm S D\end{array}$ & p-value \\
\hline $\begin{array}{l}\text { Sodium } \\
\text { (mmol/L) }\end{array}$ & $139.43 \pm 3.85$ & $133.58 \pm 7.8$ & $<0.001$ \\
$\begin{array}{l}\text { Potassium } \\
(\mathrm{mmol} / \mathrm{L})\end{array}$ & $4.15 \pm 0.43$ & $3.64 \pm 0.65$ & $<0.001$ \\
$\begin{array}{l}\text { Calcium } \\
\text { (mmol/L) }\end{array}$ & $2.23 \pm 0.13$ & $1.67 \pm 0.29$ & $<0.001$ \\
$\begin{array}{l}\text { Corrected } \\
\text { Calcium }\end{array}$ & $2.19 \pm 0.15$ & $1.74 \pm 0.32$ & $<0.001$ \\
$\begin{array}{l}\text { Phosphorus } \\
\text { (mmol/L) }\end{array}$ & $1.05 \pm 0.15$ & $0.75 \pm 0.20$ & $<0.001$ \\
$\begin{array}{l}\text { Magnesium } \\
\text { (mmol/L) }\end{array}$ & $0.85 \pm 0.06$ & $0.67 \pm 0.16$ & $<0.001$ \\
\hline
\end{tabular}

Among 90 chronic alcohol abusers, 44 patients $(50 \%)$ had a borderline hyponatremia $(<135$ $\mathrm{mmol} / \mathrm{L}$ ), and 28 patients $(31 \%)$ had borderline hypokalemia $(<3.5 \mathrm{mmol} / \mathrm{L})$.

\section{Discussion}

In chronic alcoholism the toxic effects of acetaldehyde which is formed during the metabolism of ethanol, result in a generalized reduction in the reabsorptive ability of the proximal tubular cells of the kidney. Serum Sodium and Potassium level were lowered in cases while comparing to controls. Among the chronic alcoholic patients, $40 \%$ showed hyponatremia and $25.8 \%$ showed hypokalemia. In the study of Anderson et.al shows alcoholic patients with serum sodium level of less than $130 \mathrm{mmol}$ per liter generally reflects the inability of the kidneys to handle free water, making water restriction a necessary consideration [7] which support my study.

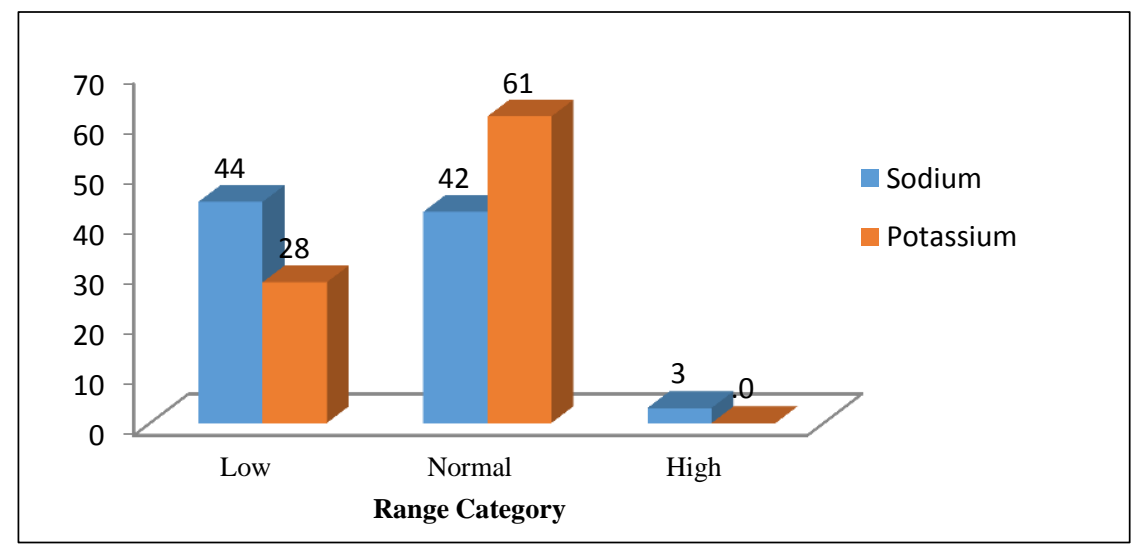

Figure 2. Electrolyte levels in cases 
Whole-body potassium stores are often depleted in alcoholic patients. It may be due to impaired reabsorption of potassium by the damaged renal tubular cells, along with co-existent hypomagnesemia [8]. Initial serum potassium levels in patients admitted to hospital may be low due to secondary hyper-aldosteronism, volume depletion from vomiting or diarrhoea, use of nonpotassium- sparing diuretic agents, or inadequate diet.

Among chronic alcoholic patients, $67.6 \%$ have lower normal calcium level. However, only 37 patients $(32.9 \%)$ had true hypocalcaemia when the corrected serum calcium was calculated. Among the electrolyte abnormalities observed in chronic alcoholic patients, hypocalcaemia is a common feature and may be evoked by various pathophysiologic [9] mechanisms, which are not yet well delineated [10-12]. The effect of ethanol in decreasing the $\mathrm{Na}+\mathrm{K}+$-ATPase activity in the proximal tubular cells may result in a decrease in the tubular reabsorption of calcium [13]. The suppressed secretion of PTH resulting from acute alcohol consumption [14] or hypomagnesaemia [15] could further contribute to the decreased tubular reabsorption of calcium.

Hypophosphatemia is common in the alcoholic patient $[16,17]$ which was also observed in our study. With long term alcohol use, phosphate depletion may result from insufficient dietary intake, impaired intestinal absorption because of vomiting, diarrhoea, use of phosphate-binding antacids, increased cellular uptake due to respiratory alkalosis, and increased urinary phosphate losses caused by alcohol directly [18, 19]. Metabolic acidosis may further enhance this alcohol-caused renal loss of phosphate by reducing intracellular phosphorylation, creating an intracellular-to-extracellular shift of phosphate [20].

Chronic alcoholic patients had depleted magnesium level than normal in this study which correlates the study of Sullivan et al that shows thirty percent of all alcoholics and $86 \%$ of those with delirium tremens had hypomagnesaemia during the first 24-48 hours after admission to a hospital [21].Causes include poor intake, increased urinary losses, vomiting, diarrhoea, and ketosis [21-23]. Magnesium deficiency in alcoholic persons include use of diuretic agents, dietary inadequacy, malabsorption, chronic diarrhoea, protracted vomiting or nasogastric suctioning, increased cellular uptake from respiratory alkalosis secondary to the hyperventilation associated with alcohol withdrawal states, and increased ethanol induced renal excretion [24]. Alcohol-induced hypomagnesaemia produces both a reduction in target organ sensitivity to parathormone and a reduction in parathormone secretion, which results in hypophosphatemia and hypocalcaemia $[25,26]$.

\section{Conclusion}

Hyponatremia occurs more frequently in chronic alcoholics. Hypomagnesaemia with its consequences (hypokalemia and hypocalcaemia) and hypophosphatemia are the most common electrolyte abnormalities found in chronic alcoholic patients. So, rapid recognition of all these abnormalities is of paramount importance for their appropriate management to lessen morbidity and mortality in such patients as the defects are transient and are reversible by abstinence of alcohol.

Conflict of Interest: None declared

\section{REFERENCES}

1. World Health Organization. (WHO). Global status report on alcohol and health. 2011; Available at: http://www. who.int/substance abuse/publications/global alcohol_ report/msbgsruprofiles.pdf. Acessed May 2012.

2. Lieber CS, ed. Medical and nutritional complications of alcoholism: mechanisms and management. New York: Plenum Press, 1992

3. Evenson ME. Ion selective electrode. In: Burtis CA, Ashwood ER ,eds. Tietz textbook of clinical chemistry, 3rd ed. Philadelphia: WB Saunders Co, 1999: 75-93

4. Lorentz K. Improved determination of serum calcium with 2cresolphthaleincomplexone.ClinChi mActa 1982; 126:327-34

5. Wentz PW, Savory J, Cross RE. Improved method for measurement of inorganic phosphate in serum with a centrifugal analyzer. Clin Chem 1976; 22:257-60.

6. Abernethy $\mathrm{MH}$, Fowler RT. Micellar improvement the calmagite compleximetric measurement of magnesium in plasma. Clin Chem 1982; 28:520-2.
7. Anderson RJ: Hyponatremia: A prospective analysis of its epidemiology and the pathogenic role of vasopressin. Ann Intern Med 1985; 102:164-168.

8. Soler NG, Jain S, James H, Paton A: Potassium status of patients with cirrhosis. Gut 1976; 17:152-157.

9. Whitecomb DC, Block GD. Association of acetaminophen hepatotoxicity with fasting and ethanol use. JAMA 1994; 272:184550.

10. Vamvakas S, Teschner M, Bahner $\mathrm{U}$, Heidland A: Alcohol abuse: Potential role in electrolyte 
disturbances and kidney diseases. ClinNephrol 1998; 49:205-213.

11. De Marchi S, Cecchin E, Basile A, Bertotti A, Nardini R, Bartoli E: Renal tubular dysfunction in chronic alcoholic abuse - Effects of abstinence. N Engl J Med 1993; 329:1927-1934.

12. Elisaf M, Merkouropoulos M, Tsianos EV, Siamopoulos KC: Acidbase and electrolyte abnormalities in alcoholic patients. Miner Electrolyte Metab1994; 20:274-281.

13. Parenti P, Giorbana B, Hanozet GM: In vitro effect of ethanol on sodium and glucose transport in rabbit renal brush border membrane vesicles. Biochim Biophys Acta 1991; 1070:92-98.

14. Laitinen K, Lamberg-Allardt C, Tunninen R, Karonen SL, TähteläR,Ylikahri R, Välimäki M: Transient hypoparathyroidism during acute alcohol intoxication. $\mathrm{N}$ Engl J Med 1991; 324:721-727.
15. Shils ME: Magnesium, calcium and parathyroid interaction. Ann NY Acad Sci 1980;355:165-178

16. Halavy J, Bulvik S: Severe hypophosphatemia in hospitalized patients. Arch Intern Med 1988; 148:153-155.

17. Knochel JP: Hypophosphatemia in the alcoholic. Arch Intern Med $1980 ; 140: 613-615$.

18. Knochel JP: The pathophysiology and clinical characteristics of severehypophosphatemia. Arch Intern Med 1977; 137:203-220.

19. Yu GC, Lee DBN: Clinical disorders of phosphorus metabolism. West J Med 1987; 147:569-576

20. Schaefer RA, Teschner M, Heidland KA: Alterations of water, electrolyte and acid-base homeostasis in the alcoholic. Miner Electrolyte Metab 1987; 13:1-6.

21. Sullivan, I. F., Wolpert, P. W., Williams, R., Egan, I. D. 1969. Serummagnesium in chronic alcoholism. Ann. NY Acad. Sci. 162:947-62
22. Flink, E. B. Magnesium deficiency in alcoholism. Alcoholism. 1986; 10:590-94.

23. Flink, E. B., Stutzman, F., Anderson, A. R., Konig, T., Fraser, $\mathrm{R}$, et al. Magnesium deficiency after pro-longed parenteral fluid administration and after chronic alcoholism complicated by delerium tremens. J. Lab. Clin.Med. 1954. 43: 169-83.

24. Whang R: Magnesium deficiency: Pathogenesis, prevalence, and clinical implications. Am J Med 1987; 82(suppl 3A):24-29.

25. Freitag JJ, Martin KJ, Carvades MB, et al: Evidence for skeletal resistance toparathyroid hormone in magnesium deficiency studies in isolated perfusedbone. J Clin Invest 1979; 64:1238-1244.

26. Miller PD, Krebs RA, Neal BJ, et al: Hypomagnesemia suppression of secondary hyperparathyroidism in chronic renal failure. JAMA 1979; 241:722-723. 